\title{
GOIÂNIA: cidade de pedras e de palavras
}

Márcia Metran de Mello

\author{
Curso: Doutorado em Sociologia \\ Data de defesa da tese: $1^{\circ}$ de outubro de 2004 \\ Orientadora: Prof ${ }^{a} \mathrm{Dr}^{\mathrm{a}}$ Barbara Freitag Rouanet
}

\section{Resumo}

"Goiânia: cidade de pedras e de palavras" trabalha, principalmente, com o imaginário urbano. É uma pesquisa que quer ver emergir a cidade oculta no imaginário de seus habitantes. Considerando-se que a cidade pode ser desvelada pela justaposição de olhares e discursos, opta-se por eleger como fonte de estudos, o espaço urbano e a literatura.

O espaço urbano, denominado "cidade de pedras", tem como enfoque o plano urbanístico de Goiânia e as diferentes manifestações arquitetônicas que surgiram ao longo de sua existência. As análises buscam captar o dinamismo da vida urbana e seus múltiplos significados, atribuídos pela população e pelo poder público. Nesse sentido, a retrospectiva ao passado é necessária para um entendimento mais amplo da cidade de hoje.

A "cidade de palavras", ou seja, a cidade vista pela literatura, lança luz sobre as representações literárias feitas sobre a Goiânia de hoje. Não se trata, porém, de crítica literária; a literatura é suporte para estudos de cunho sociológico. Com esse intuito, investiga-se toda a produção de crônicas publicadas, durante o ano de 2003, nos dois principais jornais da capital de Goiás, O Popular e Diário da 
Manhã, totalizando 520 textos. Nesses escritos, a cidade imaginária apresenta-se nas entrelinhas.

"A cidade de pedras" e "a cidade de palavras" conectam-se e entrecruzam suas significações. A compreensão de uma leva à elucidação da outra.

Palavras-chave: Goiânia, imaginário urbano, espaço urbano, literatura. 